\title{
Tree-related subsidence: Pruning is not the answer
}

Received (in revised form): 8th April, 2005

Dealga P. O’Callaghan BSc (Hons), PhD, MICFor, FArborA, MAE is a senior practice consultant with OCA UK Ltd based at its Liverpool office where he is the Head of Legal \& Expert Services company-wide as well as the Regional Planning Manager. He holds an honours baccalaureate degree and $\mathrm{ahD}$ in the field of biology. He is a Chartered Forester, a Fellow of the Arboricultural Association, a Member of the Institute of Biology and a Chartered European Biologist. He is a practising member of the Academy of Experts and a Law Society Accredited \& Checked Expert Witness. He is an Adjunct Professor of Forest Resources at Clemson University, South Carolina, USA and a Visiting Lecturer at Myerscough College in Lancashire. DrO'Callaghan has over 20 years' experience as an arboricultural consultant and considerable experience in the field of tree-related subsidence. He has given evidence in many civil and criminal cases in the English and Irish court systems and on the Isle of Man.

Oisin Kelly BSc, MIBiol, MAE

is a senior practice consultant at OCA UK Ltd based at its Colchester office where he is Head of Technical Services company-wide. He holds an honours baccalaureate degree in forestry from the University of Aberdeen. He is a Member of the Institute of Biology and a Chartered Biologist, a practising Associate of the Academy of Experts and a Law Society Accredited \& Checked Expert Witness. Mr Kelly has 12 years' experience in public sector arboriculture in various London boroughs and has considerable experience in the area of tree-related subsidence. He has given evidence in numerous civil cases in England.

\begin{abstract}
Building subsidence is a major problem in the UK and has been for many years. Most subsidence problems are tree-related and the cost to the insurance sector runs into hundreds of millions of pounds a year. Subsidence damage ranges from minor cracking to significant structural damage and trees are sometimes viewed negatively because of their role in subsidence damage. There are over 150 million urban trees in Britain and a significant majority of these are legally protected by tree preservation orders or by virtue of the fact that they are in conservation areas. There has been simplistic and erroneous advice available for a number of years that is based on a false premise that pruning offers a means to control tree water use sufficiently to provide a remedy for tree-related subsidence. This paper presents a factual account of the biology involved in how trees use water, together with the results of recent research into the subject, that cogently dispose of the false premise that has dominated the subject since the 1970s. A simple 'model tree' is presented in the context of clay soils, climate, building guidelines, the housing stock and management options. Recent case law in this area is placed in the context of the legal framework surrounding the issue and the effect of tree removals on the nation's urban

tree population is discussed.
\end{abstract}

Head of Legal \& Expert Services OCA UK Ltd, Goodlass House Goodlass Road, Speke Liverpool, L24 9HJ, UK Tel: + 44 (o) 1514857200 Fax: + 44 (o)151 4857171 E-mail: dealgao@oca-arb.co.uk 
Keywords:

subsidence, tree, shrinkable clay, water use, climate, MORECS, vegetation, pruning

\section{THE PROBLEM}

The UK is one of the most densely populated areas of the world. It has a population of over 65 million with over 25 million residential homes sited on a land area of $244,750 \mathrm{~km}^{2}$ (DETR, 1991). The number of residential homes is increasing rapidly with government approval and encouragement. The ratio of the urban to the rural population is one of the highest in the world and reflects the nature of industrial development within the UK from the industrial revolution to the present day. The urban conurbations contain trees, which are maintained as part of a sustainable green environment. The benefits of urban trees to the health and wellbeing of the population are recognised and the UK has the most sophisticated system of legal protection for trees in the world. Some think the system is cumbersome and arcane, but government surveys reveal over 90 per cent support for the system (Batho, 1990).

There is no exact figure available for the number of urban trees in Britain but various estimates using government and non-government sources suggest that the urban tree population is in the region of 150 million and the total population of amenity trees is over 1 billion. These estimates are supported by the results of definitive surveys that have been undertaken in specific urban conurbations. For example, the City of Liverpool has 500,000 trees in public ownership (and the same again on private land), in addition, it has over 125 hectares of woodland. Task Force Trees revealed that there are over 400,000 street trees and 6 million trees of other types (excluding woodlands) in London. The figure of 6 million trees within 33 boroughs and 500,000 in one major urban conurbation, when extrapolated over the 550 or so local authorities nationwide, forms the basis for the estimates given above.

The UK is heavily urbanised and the interface between human structures and trees is not always an easy one. The benefits that urban trees confer, in fiscal and physiological/psychological terms, have been well documented (Davey Resource Group, 1993; NUFU 1998, 2005); however, the uneasy relationship between trees and people arises in two distinct ways. First, any house builder/developer will attest to the constraints that trees place upon potential development sites at the planning stage. Secondly, trees cause damage to buildings through subsidence, which is caused by tree growth functions, and this is the topic of this paper.

\section{THE NATURE OF TREE DAMAGE TO BUILDINGS}

\section{Damage to buildings}

Trees can cause damage to structures and buildings either directly or indirectly. Direct damage is usually obvious and spectacular, ie trees can fail for many reasons, but this is usually associated with storms and strike buildings, power lines, vehicles and, in some instances, people. The consequences of such direct damage usually make media headlines. In addition, trees can cause direct damage to buildings and structures by 
Clay shrinkage causing downward movement of foundations pressures exerted on the structures through growth; however, this is comparatively rare and has been addressed in some detail elsewhere (Biddle, 1998).

Of more relevance is the ability of trees to cause subsidence damage to buildings through normal growth functions. Subsidence has numerous possible causes, for example, mining collapse, erosion, consolidation settlement, clay softening and clay shrinkage. Only the latter of these, ie clay shrinkage, is vegetation-related. Confusingly, however, the term subsidence is variously used to mean all, some or specifically one of these causes. Within an insurance context, the term subsidence means any cause not specifically excluded within the policy. But the term subsidence is also commonly used to refer specifically to clay shrinkage subsidence, as distinct from settlement caused by, for example, consolidation. Clay shrinkage subsidence occurs where trees (or vegetation) extract moisture from the soil causing it to shrink; however, only certain soil types are prone to moisture-related shrinkage, mostly the aptly named 'shrinkable clays'.

Subsidence damage to property in the UK is often said to be the single largest tree-related insurance problem in the country (see Figures 1 and 2). The problem was first reported in the 1940s when Ward (1947) wrote an article on 'The effects of fast growing trees and shrubs on shallow foundations', but really came to its present level of importance following the drought period of 1975/1976.

The problem has been the subject of much discussion among insurers, engineers and arboriculturists and there has been some research also, the early work being funded by the National House Building Council in the late 1970s and into the 1980s. More recently, the Building Research Establishment (BRE) has undertaken research (1999-2001) and the Office of the Deputy Prime Minister (ODPM) funded a five-year study into 'Controlling Water Use of Trees to Alleviate Subsidence Risk' (Hipps, 2004).

Regardless of the research and published data, there is still a lot of confusion among the principal technical professionals involved with the problem. Put simply, the problem is the result of downward movement of foundations sufficient to cause cracking, it is largely cosmetic in nature and is generally an equity rather than a structural issue. But the problem is obviously more complex than that and comprises the following elements.

- The value of urban trees

- The climate

- Clay soils

- The effects of vegetation on clay soil

- The clay soil, vegetation and climate continuum

- Managing vegetation implicated in subsidence

- The housing stock

- The insurance and legal framework.

It is a fact that trees contribute significantly to subsidence in areas with clay soil, where the soil 'shrinks and swells' in response to the addition or 


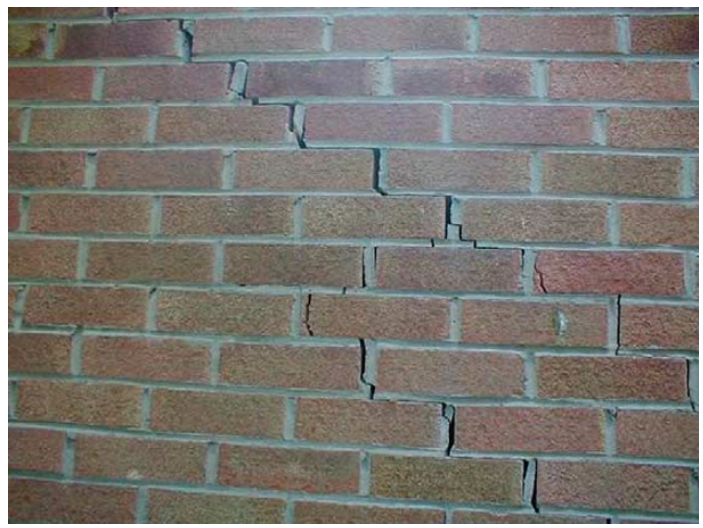

Figure 1: Cracks to the side of a house in Nottingham caused by maple trees in 2003 growing within $5 \mathrm{~m}$ of the building

abstraction of water. It is estimated that over 60 per cent of the nation's housing stock is built on shrinkable clay soil and is thus prone to subsidence.

\section{THE INSURANCE COST OF SUBSIDENCE}

The average annual cost of building subsidence to insurers is over $£ 400 \mathrm{~m}$, which represents approximately 40,000 claims per year. The number of claims and the cost of those claims for the years 1989-2004 are shown in Figure 3. The experience of the major loss adjusters is that approximately $50-70$ per cent of these claims are repudiated, ie they are rejected as invalid, mostly because damage is identified as being due to some non-

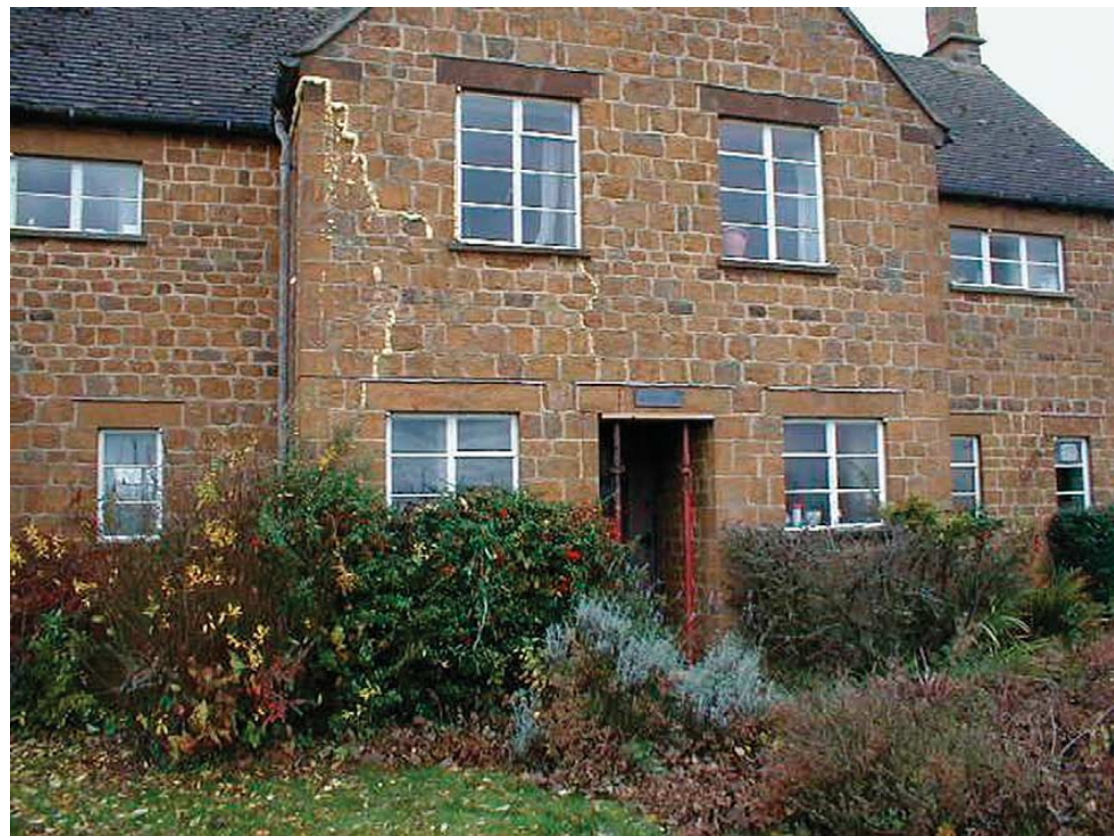

Figure 2: Severe cracking to a sandstone house in Oxfordshire caused by fruit trees growing in the garden (note the foam filling in the cracks and the jacks supporting the lintel) 


\section{Insurance costs of f40om per annnum}

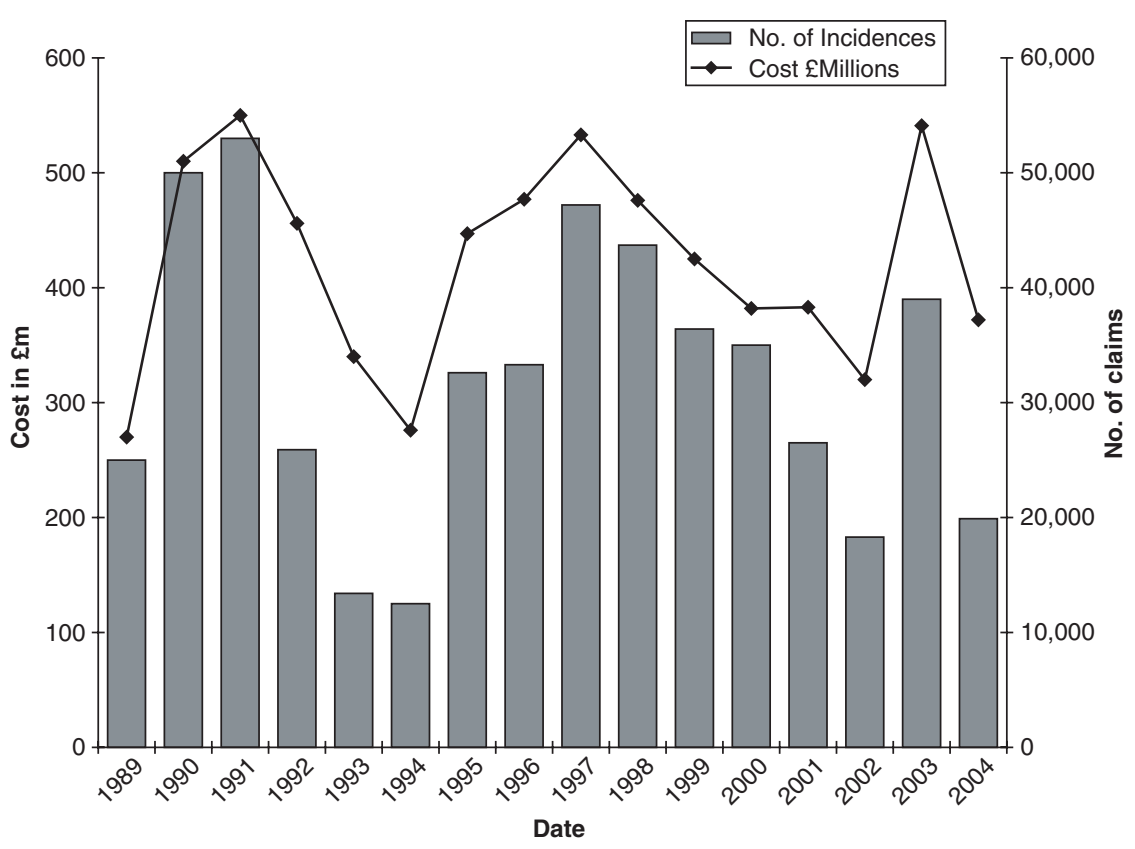

Figure 3: The cost of subsidence: The number of claims (line) and the cost of claims (bar) from 1989 to 2004. Source. The Association of British Insurers

subsidence-related cause, not covered by the policy. Of the valid claims, around 80 per cent are tree-related, with perhaps $10-15$ per cent being related to drains and the remainder due to other causes. It is a fact that treerelated claims cost more and take longer to resolve than other causes of subsidence.

The peaks in cost and number of claims in Figure 3 represent periods of drought, ie between 1989-1992, 1995-1997 and 2003. Over the 16-year period between 1989-2004 the total cost to the industry was close to $£ 6.8$ bn, which produces an annual average cost of $£ 422 \mathrm{~m}$. Significant drought years like 2003, however, skew the data because the typical annual insurance spend on subsidence claims is less than $£ 400 \mathrm{~m}$. The hidden cost of subsidence is that, until comparatively recently, the average duration of a claim was in excess of 18 months and thousands of households suffered lengthy disruption while the technical professionals dealt with the repair.

\section{THE VALUE OF URBAN TREES}

As stated above, it has long been known that trees and other vegetation in urban areas confer many benefits to the human population (NUFU, 1998, 2005). It is now established that urban vegetation plays an important role in urban sustainability and the socioeconomic stability of communities. Trees are valued and can generate high levels of emotion when they are removed or threatened with removal. Although there is no definition of a tree within English law, trees benefit from protection under a number of statutes, not least of which is the Town \& Country Planning Act, which places a statutory duty upon local authorities to make provision for the protection and planting of trees and, indeed, provides them with the power 


\section{Parts of the UK are classifed as semi-arid}

to protect trees by means of tree preservation orders (TPO). Many trees are also planted and maintained along public highways in close proximity to properties on shrinkable clay soils and it is these areas that generate the biggest problem for technical professionals trying to resolve subsidence problems.

\section{THE CLIMATE AND CLAY SOILS}

The climate of the UK is influenced by the weather systems of the Atlantic Ocean and the continental land mass of Europe, and both factors act on the geography of the country in a dynamic and complex manner. The west and north of the country comprise upland on to which the Atlantic weather systems fall. The south and east are generally at or very near sea level and their physical proximity to mainland Europe leads to a more continental climate than in the north and west, with longer summers, higher average temperatures and lower average rainfall. Despite the influence of the Atlantic, the UK is relatively poor in water resources. River systems are short and fed from small upland watersheds. The large centres of the population, particularly in the Thames Valley, and the low average rainfall of the south and east combine to produce a poor water environment. Counties such as Essex are actually classified as semi-arid, which is an indication of the relative scarcity of available water in eastern counties. Additionally, the impact of the dry summers from the 1970s onwards, together with the low winter rainfall has had an effect upon the volume of moisture in clay soils (Marsh and Monkhouse, 1992).

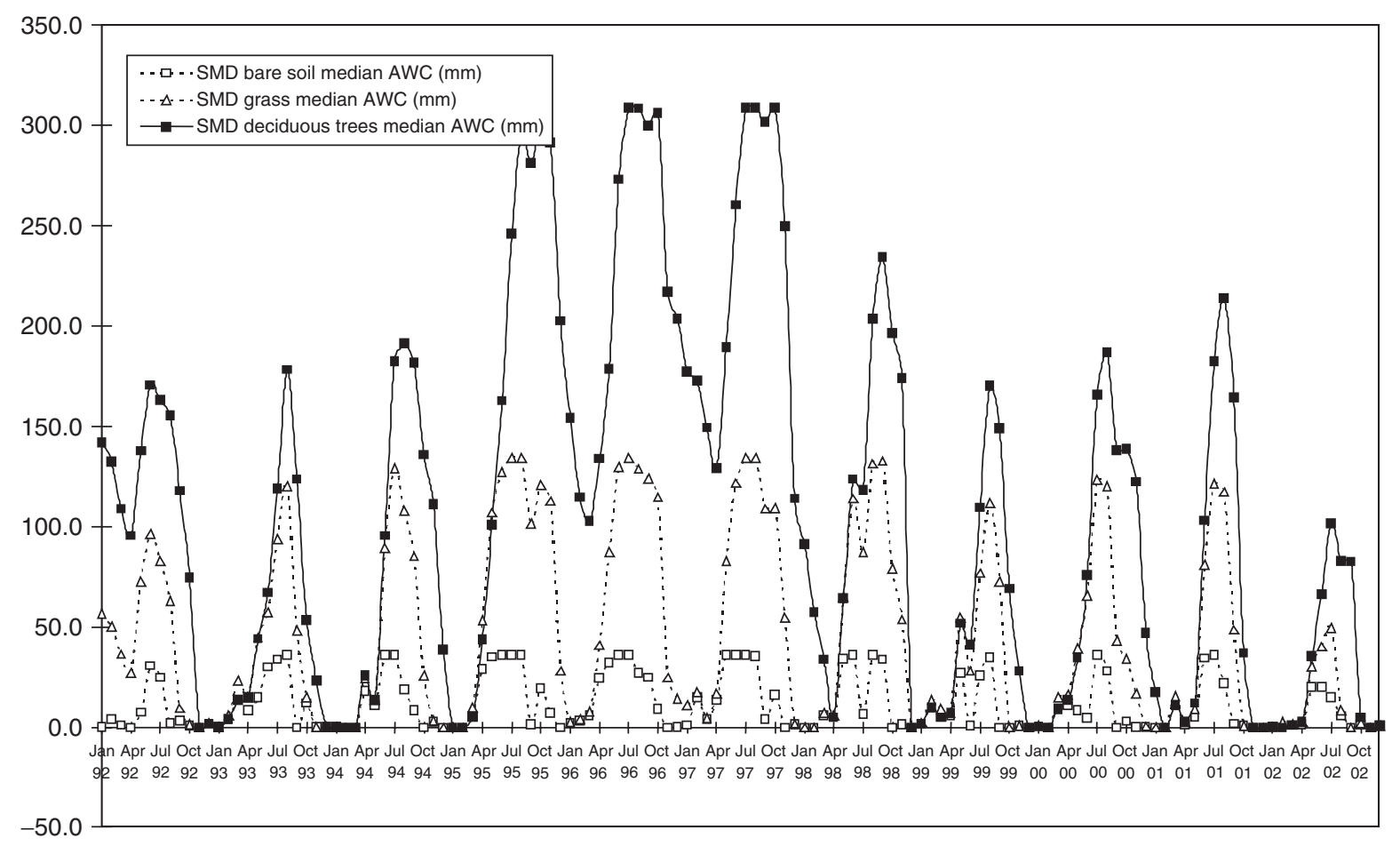

Figure 4: Example MORECS data for a site in north London. Source: Meteorological Office (2004) 


\section{Deciduous trees cause soil moisture deficits, which can be severe}

The normal annual cycle of water loss from clay soil in the presence of vegetation is easily seen using the Meteorological Office Rainfall and Evapotranspirational Calculating System (MORECS). Figure 4 shows water loss in millimetres beginning at the start of the new year when the soil is at field capacity ( $\mathrm{FC}=0$, a fully hydrated clay soil). The soils begin to dry as evapotranspiration accelerates through the spring and summer, showing peak values towards the middle of the summer, and autumn and winter rains usually begin to rehydrate the soil. If the overall rehydration level is less than the evapotranspirational loss, then a soil moisture deficit (SMD) will develop. If this continues for a prolonged period then the SMD becomes persistent and progressive ground movements can occur (Lawson, 1993).

The data in Figure 4 clearly show the significance of vegetation to the abstraction of water from clay soil. Additionally, they show water loss from bare soil, grass and deciduous trees. Under bare soil the maximum SMD during any year is $20-25 \mathrm{~mm}$, leaving between $150-250 \mathrm{~mm}$ of water available for plants in any $1,000 \mathrm{~mm}$ of clay soil. The effect of sunlight alone, even during periods of drought, is minimal. Under grass the SMD develops earlier in the year than if deciduous trees are involved where it can be significant.

Deciduous trees start to influence the SMD later than grass and, following 'bud burst', it is July before trees overtake the water loss of grass. Trees transpire water against the inflow from summer rains, which grass does less successfully. Deciduous trees maintain a severe deficit until the end of the year. If there is a persistent SMD from the previous year, the process starts again but from an existing deficit, which can precipitate a subsidence event sooner in that year.

Clay soils are distributed across the UK but are concentrated in the south and east. Clay is a complex chemical medium and its primary interest, in biological terms, relating to plant water use is that clay intercepts precipitation and binds water to its structure against gravitational energy. Plants, including deciduous trees, can access a percentage of the bound water and it is the shrinking of the clay volume as water is removed that can lead to movements in any structure founded on clay. It is important to appreciate that it is the volume of water in the soil that changes and not the clay itself.

The clay content of soil can be tested for its cohesiveness by reference to its plasticity index (PI). The most commonly used measure is the one- or four-point Cone Penetrometer Method as described in

Table I: Classifications of clay soil for comparative purposes based on the plasticity index $(\mathrm{Pl})$

\begin{tabular}{lr}
\hline Shrinkage potential & PI(\%) \\
\hline Non-plastic & $<10$ \\
Low plastic & $10-20$ \\
Medium plastic & $20-40$ \\
Highly plastic & $40-60$ \\
Very highly plastic & $>60$ \\
\hline
\end{tabular}


BS1377 Part 2 (BSI, 1990). The method analyses the soil's upper and lower plastic limits (ie too wet to paste or too dry to retain a moulded form). The difference between the two limits is the PI and is normally represented as a percentage. The BRE and others generally classify clay soil for comparative purposes based on the PI. Table 1 represents a compilation of the various comparative systems generally used to assess the degree to which clay soil is prone to movement as water is abstracted.

\section{THE HOUSING STOCK}

Within the UK the spatial arrangement of population centres has resulted in buildings being located in areas prone to subsidence damage.

The social, political and economic dominance of the south-east of the country has resulted in a significant portion of the population living in this area. Housing densities and plot sizes often combine to produce an overcrowded environment in which the establishment and growth of trees is difficult. The presence of large numbers of houses built since 1900, the scarcity of building land and post-war rebuilding programmes, together with the comparatively recent (1985) development of building standards that take into account shrinkable soil and trees, have combined to predispose much of the housing stock in the South-East to differential structural movements.

\section{A SIMPLE MODEL TREE}

It is important at this juncture to understand how trees function and grow in order to appreciate how they can cause subsidence damage and to understand the management options for repairs where trees are present. To facilitate this understanding, this paper presents a 'simple model' of how a tree functions with regard to water use.

Although not defined in law, trees are generally considered to be large, dynamic, woody perennials that are self-optimising. In effect they are dynamic pumping mechanisms and essentially have three component parts:

- Roots for anchorage, storage and absorption;

- Scaffolds containing branches, sub-branches and twigs that carry leaves;

- Trunk (bole or stem) that connects the other two parts.

Roots absorb water and the three major nutrients: nitrogen $(\mathrm{N})$, phosphate $(\mathrm{P})$ and potassium $(\mathrm{K})$, together with between 13-17 micronutrients.

Water and nutrients are transported from the roots to the shoots through the wood (xylem). Leaves contain chlorophyll where the process of photosynthesis combines water from the soil with carbon dioxide from the atmosphere and energy from sunlight to produce sugars (photosynthate), releasing oxygen back into the atmosphere. The sugars are simple carbohydrates such as glucose, fructose and sucrose that are transported from the shoots to the roots and other areas in the inner bark or phloem tissue. 


\section{Trees are biological water pumps}

A tree stores energy in the form of starch, which is a long-chain molecule comprised of multiples of glucose molecules. The presence of starch in tree tissues can provide an indication of its state of health and its presence in roots recovered from the underside of foundations is generally taken as proof that the roots are alive.

Leaves also provide the mechanism by which water leaves the tree. Water is absorbed through the roots and moved up the wood or xylem to the leaves where some is used in photosynthesis and the rest evaporated to the air through structures called stomata. This process is called transpiration. Thus, the leaves regulate the water use of trees and herein lies the basis for the simplistic, erroneous advice that removal of branches (and with them leaves) will reduce the amount of water a tree will use and thus reduce its ability to cause subsidence damage. This idea has been the 'central dogma' in the area of tree-related subsidence for many years. The theory is as follows. Trees take moisture out of the soil (they have to in order to survive); trees lose moisture by transpiration through their leaves; if a tree is pruned to remove say 30 per cent of the crown and associated foliage then the amount of water that tree will use is reduced by a similar proportion, ie 30 per cent; if pruning is maintained at that level on a regular basis then the lower level of moisture use by that tree is maintained as long as the pruning regime is in place. Put simply, the 'dogma' states that pruning offers a means to control tree water use sufficiently to provide a remedy for tree-related subsidence.

This 'dogma' does not actually make any biological sense, however, as there is no linear relationship between foliage volume and the amount of water lost. Being dynamic organisms, trees react to pruning by trying to restore the root to shoot ratio and do so by producing as many leaves as they can from meristematic tissue. These new leaves are usually juvenile leaves with a larger surface area and generally more stomata per unit of surface area. Analysis of the life cycle of deciduous trees supports this theory.

A young tree has a high leaf to mass ratio, ie many more leaves than wood. The leaves are juvenile in form with a large number of stomata and the roots are only just beginning to invade the soil environment.

Conversely, a mature tree has invested heavily in growth, particularly of roots into the soil environment, and the leaf size is diminished. A mature tree operates a sophisticated sun/shade leaf distribution strategy whereby drought-tolerant leaves (less prone to lose water) are distributed on the outside of the canopy and the leaves less tolerant of drought are distributed within a layered canopy. Loss of water through the inner leaves produces a cooling effect within the crown, ie a biological air-conditioning plant.

When a tree is heavily reduced or topped to remove the foliage, this does not immediately affect the root plate, which remains at the prepruning volume. Trees do not easily give up tissues in which they have invested, rather they react by trying to restore the leaf volume, ie to restore the balance between the volume of root and the canopy, or the root to shoot ratio. The tree produces as many new leaves as it can and new tissue, which elongates rapidly in an attempt to produce a layered canopy. In response to pruning certain morphological changes also occur at the level 


\section{Heavily pruned trees use more water}

\section{Research on healthy and stressed trees produced similar results}

of the leaf and in terms of crown architecture. Leaves produced following heavy pruning have typically larger surface areas, more stomata per unit of leaf surface area and thinner cuticles, all of which may increase the loss of water per unit of the leaf surface area. Trees may also compensate for the loss of leaf surface area by keeping their stomata open for longer periods.

Recent research also supports the opinion that the 'dogma' is fatally flawed. The results of the ODPM-sponsored research undertaken by the HortLINK at East Malling Research (Hipps, 2004) shows that pruning within arboricultural industry guidelines is ineffective in controlling water use. The research clearly and unequivocally demonstrates that thinning has no effect at all. Only a crown reduction of over 70 per cent by volume, which equates to a 35 per cent crown reduction, has any effect and then it is for one season only (if that) and the reduced trees use more water in the following season (Hipps, 2004). In essence the HortLINK study concludes:

- Total tree water use (transpiration) was reduced by crown reduction in the year of pruning.

- Total tree water use (transpiration) was unaffected by crown thinning in the year of pruning.

- Crown reduction reduced soil drying by trees in the year of pruning, but the effects were generally small and disappeared within the following season, unless reduction was severe, in which case the effects were larger and persisted for up to two years.

- Crown thinning did not reduce soil drying.

- Crown reduction increased subsequent shoot extension and epicormic growth.

- The new shoots grew more rapidly and produced larger leaves.

Interestingly, the HortLINK results mirror the findings of the BRE at the Queens Park Estate in Westminster (BRE, 2001). Here, cracks in buildings with London plane trees in the streets outside them were monitored over a ten-year period. The trees were pollarded at the start of the monitoring and maintained as pollards on a biannual basis. The monitoring showed that immediately following pollarding crack movement slowed or stopped, but the season following pruning the cracks opened again and the openings were larger in each successive year. One tree was removed and the crack movement in the building opposite the location of that tree effectively ceased. The BRE project pre-dated the HortLINK research by nine years and finished just as the HortLINK project got underway.

Quite apart from the fact that both sets of data independently derived support for the concept that pruning does not control water use in trees and effectively does not reduce subsidence damage, another interesting point is that the HortLINK project utilised healthy trees growing in excellent conditions, while the BRE data were derived from street trees in Westminster. Thus, healthy and stressed trees produced similar results, all of which prove that the old 'central dogma' no longer applies. 
It must be emphasised that trees are considerably more complex than this simple model. Simple as it is, however, this model does demonstrate the processes of growth and water use that are germane to the subject of subsidence at this level. A full review of 'the model tree' can be found in Lawson (2004).

\section{BUILDING GUIDELINES}

The flaws in the 'dogma', which have now been addressed through research, are still potentially serious and the National House Building Council (NHBC) has produced guidance for builders calculating foundation depths when they are building near trees (NHBC, 2003). This guidance classifies trees as 'high', 'moderate' or 'low' in their demand for water and contains a table that categorises the most common species of tree into these categories. The essence of the guidance is that the tree is identified and its 'water demand' category obtained. Then, having assessed the PI of the clay soil, using a formula that interpolates between the ultimate height of the tree and the distance it is from the proposed building, one can calculate how deep the foundations should be to resist tree-related subsidence. It is emphasised that this is a construction industry document and it is not an arboricultural document, although an arboriculturist advised the NHBC in the production of the original document in the 1970s. The document works exceptionally well for newbuild developments and the cost benefits for the NHBC are clear. It should not be used retrospectively on older buildings that pre-date the advice, however, and it is neither a diagnostic tool for the prediction of the likelihood of subsidence damage nor a risk assessment model (see Figure 5).

The NHBC 'water demand' categories are not supported by any biological research and, in light of the research set out above, must also be regarded as irrelevant. The term 'water demand' has no biological significance (O'Callaghan and Lawson, 1995; Lawson and O'Callaghan, 1995) and is not used in the arboricultural industry. In fact, the arboriculturist who advised the NHBC states clearly that 'water demand' has no relevance and that the main object of his approach was to

The term 'water demand' has no biological significance and is meaningless demonstrate to builders that trees differed in the lateral and vertical distribution of their roots (Biddle, 1993: personal comment). It is hard to accept that a large oak tree utilises significantly more water than a large beech, particularly when both species belong to the same family

(Fagaceae). The significant difference between oak and beech trees is not in the above-ground parts of the trees, but rather in the depth to which their root systems can reach. Beech is a shallow-rooting species, while oak, under the right circumstances, can root to considerable depth. This resource strategy, of having access to a greater soil depth, means the oak has a greater impact on the moisture content of clay soils at depth and on the underside of foundations.

It is worth noting that a small number of buildings constructed in line with NHBC guidance have failed during periods of drought. A significant number of these failures can be attributed to new-build, greenfield sites that were devoid of trees. The buildings were constructed 


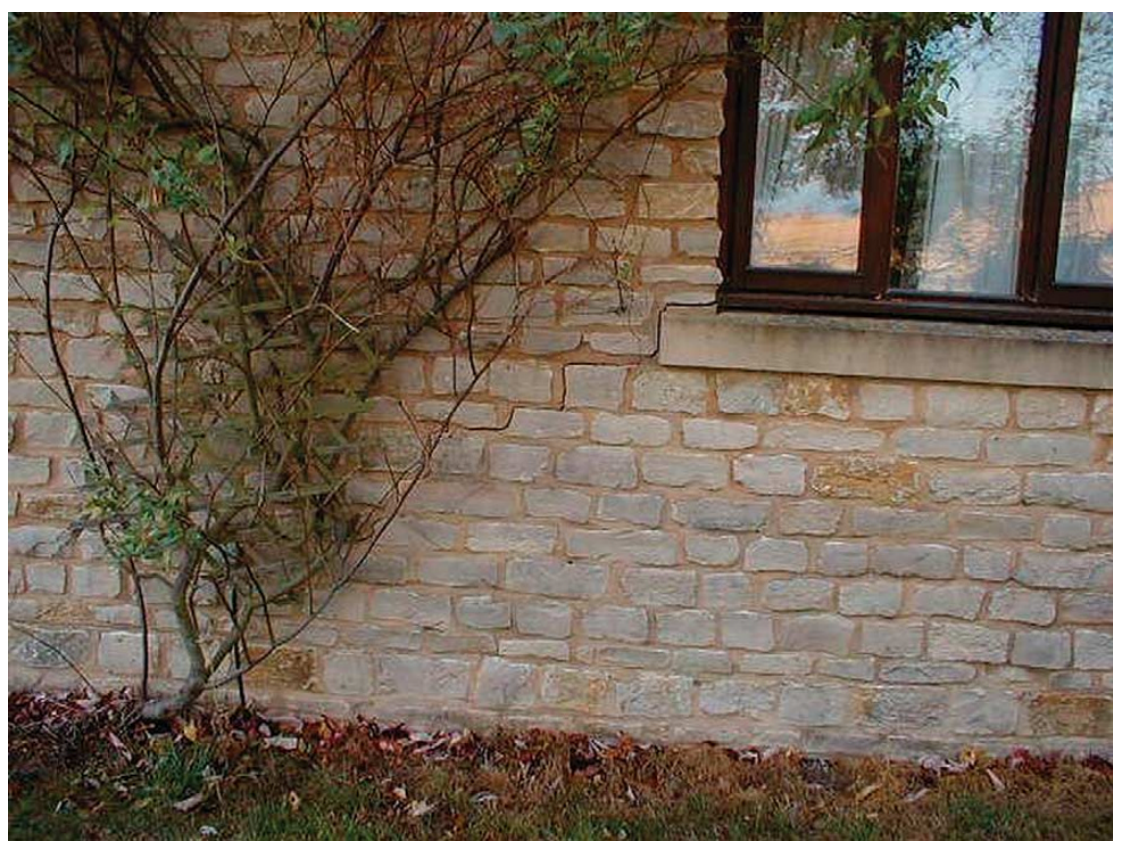

Figure 5: Cracking in a recently built house near Stratford-upon-Avon. This house is less than five years' old and the design of the foundations did not account for poplars, willows and maples growing in the garden at distances of between $10 \mathrm{~m}$ and $20 \mathrm{~m}$ from the house

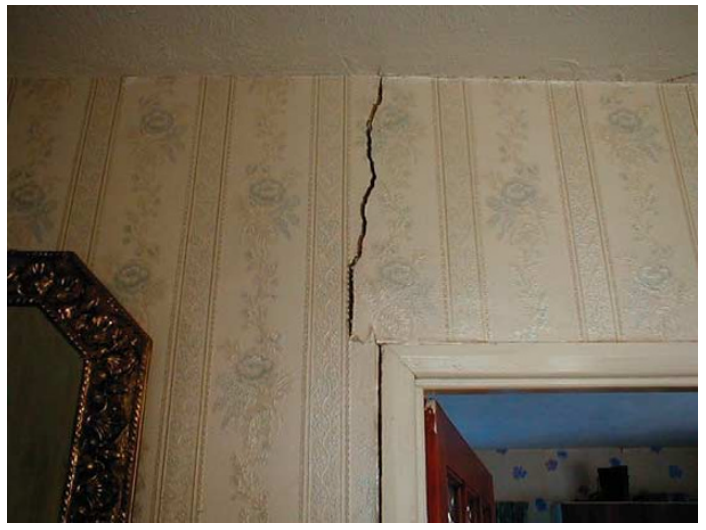

Figure 6: Internal cracking in a farmhouse in Lincolnshire caused by poplar trees $20 \mathrm{~m}$ away from the building

on foundations suitable for a site without trees, but with no anticipation that homeowners might plant trees in their gardens once they had moved in.

\section{MANAGING VEGETATION TO REDUCE SUBSIDENCE RISK}

When a subsidence event occurs and a building is damaged, a claim is made on the insurance policy. Once the claim is validated the process of dealing with the problem and repairing the building gets underway. It is 


\section{Buildings repaired in previous years where trees were retained and pruned failed in a subsequent drought year}

emphasised that an insurance policy covers risk in respect of repair not betterment. In other words, the contract between the insurer and the insured is to repair the building to the pre-damage condition. Therefore, it is in the interests of both parties that the cause of the damage - the tree(s) - is removed such that an effective repair can be made with a likelihood that it will not recur.

Previously, the practice has been to underpin the property and prune the tree, based on the knowledge of the day. It has become increasingly obvious to insurers, however, that such a high-cost remedial strategy is simply incompatible with the need to maintain policy premiums at competitive levels. In this context, with the present state of knowledge and the research data, it is obvious that the only way to ensure that there will not be a recurrence of the subsidence event after repair is to remove the tree. Pruning simply does not work. During the 2003 drought year there were numerous cases where buildings repaired/underpinned as a result of previous subsidence events failed again. In these cases, the trees had been retained and pruned, yet in a subsequent event year, the repairs failed and the buildings subsided (see Figure 6).

Based on the results of recent research and a correct interpretation of tree biology and growth, together with the authors' experience of tens of thousands of subsidence cases, it has to be concluded that pruning is not and never has been a viable option. In order to achieve a permanent repair there is no option but to remove the tree.

As stated above, the removal of trees can generate high levels of emotion and, where trees are legally protected, owned or managed by local authorities, there is usually strong resistance to their removal. Some local authority tree officers still cling to the old 'dogma', now known to be flawed. Others will take the view that the amenity value of the tree outweighs the value of the property and the distress caused to homeowners. Others will suggest alternative solutions such as root barriers, artificial stabilisation (eg underpinning) or strengthening works (eg 'helibar' reinforcement). These are costly options, however, and, within a competitive market, insurers properly will continue to seek the most cost-effective remedy, which is almost invariably tree removal.

\section{Root barriers}

Root barriers have their own inherent problems in that they create the rooting conditions and moisture gradients that encourage root growth under and around any barrier. They are costly to install and create major logistical problems associated with multiple landowners, the Construction, Design and Management (CDM) Regulations and general issues of health and safety. Furthermore, in relation to highway trees, any root barrier almost certainly will be breached by subsequent excavations for utility service maintenance etc and, as such, they provide no real prospect of a sustainable remedy.

\section{Strengthening or stabilisation works}

Attractive as strengthening or stabilisation works might be to some, they are not an option. As stated above, an insurance policy is a legally binding 
contract between the insurer and the insured. It is a commodity and there is a body of legal precedents and statute law supporting not only the insurance industry but also the rights of property owners. If a building cracks as a result of tree-related subsidence and the policyholder makes a claim, the policy only covers the repair of the building to its pre-crack condition. Insurance policies do not cover 'betterment', ie making the building better than it was before the event.

Where the cause of the damage is a tree in the ownership of a third party then, subject to the ABI Domestic Tree Root Claims Agreement and current civil tests, the owner or controlling authority of that tree will be liable for the cost of repair. Thus, this final possible option is not viable unless the tree owner is willing to bear the cost of retention.

\section{THE LEGAL FRAMEWORK}

There is a body of common law (precedents and decisions) and, indeed, statute law that governs the area of subsidence damage. The legal framework is that of the rights of property owners and insurance law and many arboriculturists tend to forget this. This area of law has nothing to do with trees per se, it has to do with landowners' rights and the English laws of tort. It is an unfortunate fact of life that trees do cause subsidence damage, which in turn affects equity and property values; in today's climate, where the economy is driven by or at least strongly influenced by property prices, the problem needs to be solved.

The current case law in this area is well summarised within:

- Solloway $v$ Hampshire County Council (1981) 79 LGR 449

- Patterson $v$ Humberside CC (1996) Const. LJ 64

- Delaware Mansions $v$ Westminster City Council (2002) 1 AC (House of Lords)

- Loftus-Brigham $v$ LB Ealing (2003) EWCA Civ.1490.

All these cases summarise and cogently restate the common law situation, which is that if trees under the control of a local authority or a third party are a material cause of subsidence damage the local authority or third party is liable for recovery costs. One only has to analyse these decisions to realise that the patience of the courts is running out against local authorities which seek to protect trees at all costs and in the face of clear evidence of their trees' involvement in subsidence cases.

The current legal position is that to establish liability the trees do

Trees only have to be a 'material cause' of the damage not have to be the 'substantive' or even 'major' cause of subsidence, just 'a material cause'. In other words, the weight of civil law and precedent is against the local authorities and for property owners' rights. In order to have a chance of recovering costs, however, the insured needs to prove that on the balance of probabilities a particular tree or trees has caused the subsidence damage. The evidential tests that are required to establish legal liability have been established over time within case law. It is suggested that in relation to tree-related 
subsidence the tests to establish liability may be summarised as follows:

- Tree roots must have encroached.

- Damage to the property must have resulted from the encroachment.

- The tree owner or controlling authority ought to have foreseen the risk of damage resulting from encroachment.

- There was something the tree owner or controlling authority reasonably could have done to reduce, minimise or eliminate the risk of damage.

All four tests are judged on the balance of probabilities. Only the first two tests relate to causation and these tests may be satisfied in a number of ways about which it is not possible to be prescriptive, in other words, 'each and every case on its own merits'. It can be said, however, that the second test can be used to verify the first. For example, if during the site investigations no roots are recovered from trial holes but there are trees within influencing distance and the pattern of distortion of the building is downward in the direction of the trees, then both tests are effectively satisfied.

In light of the legal framework, the increased costs of repair and the resistance on the part of owners or controlling authorities to permit removals, more cases are going to court. Insurers take a pragmatic view; if, in spite of all the evidence, consent for removal is not forthcoming, then an expensive underpinning/strengthening repair is made and proceedings are initiated against the owner or controlling authority for recovery of costs.

\section{SITE INVESTIGATIONS}

In the present climate, when a tree-related subsidence claim is validated, a detailed investigation of the damage and the site is undertaken as part of the claims handling process. This involves opening up trial pits and bore holes, assessing the nature of the foundations, analysis of the soil (including but not limited to measurement of the PI, moisture content, degree of desiccation and load-bearing capacity) and identification of roots recovered from the underside of foundations. An arboricultural investigation is also commissioned to ensure that all tree-related issues are addressed and that they inform the design of the repair.

The role of the arboriculturist does not necessarily stop at the site investigation. If the damage is tree-related, then the arboriculturist can assume responsibility to try and have the tree(s) removed. If the trees are the insured's own trees and not subject to any legal protection, then arrangements are made for a contractor to remove the tree. If the trees are in the ownership of domestic or commercial third parties with no legal constraints, then the arboriculturist typically will negotiate removal and make appropriate arrangements. If the trees are located within a Conservation Area and/or subject to a TPO, however, then the arboriculturist will undertake all the protocols involved in obtaining statutory permission up to and including an appeal to the Secretary of State if appropriate. 
Where the trees are in the ownership of a local authority, the arboriculturist undertakes all negotiations to try and have the trees removed. If these attempts fail and an appeal against refusal of consent to fell a tree subject to a TPO is dismissed, however, the insurer has to consider whether or not to seek recovery through the civil courts.

\section{THE EFFECTS OF SUBSIDENCE ON THE URBAN TREE POPULATION}

Tree-related subsidence has always been perceived in some quarters as a significant threat to the urban tree population. This perception has become more entrenched in light of the legal precedents and the results of the most recent research as set out above. There is no doubt that it is a significant arboricultural problem but, in the context of 150 million urban trees, it is hardly a threat to the future of the urban tree population. The issue must be assessed in its proper context.

In an average year about 40,000 subsidence claims are made. Usually between 50-70 per cent are repudiated, leaving 12,000-20,000 valid claims per year, of which a further 10 per cent or so will not be treerelated. Therefore, there are between 8,000-16,000 valid claims in an average year, the majority of which involve relatively minor vegetation and, in reality, only 30 per cent of the remainder, ie $2,400-4,800$, involve highway trees or trees covered by TPO. If each claim resulted in the removal of one tree, that would be 2,400-4,800 trees per annum out of a total urban/amenity tree population of over 150 million. Therefore, the loss of less than 5,000 highway or TPO trees per year, a large proportion of which are replaced, is not a significant threat to the urban tree population because only a very small proportion is affected. Where there is clear and substantial evidence of the involvement of trees in subsidence cases, however, local authorities ought to remove the trees or grant consent for removal, otherwise they will have to pay the cost.

Far from being a threat to the urban tree population, tree-related subsidence should be viewed as an opportunity for local authorities to review and implement researched and reasoned policies for urban tree management. If the local authorities really want to address this issue, the best way forward is to include a policy on tree-related subsidence linked to urban tree management policies within local and unitary development

Tree-related subsidence represents an opportunity for local authorities plans. If tree officers communicated more with their colleagues in forward planning and introduced such policies and management plans/strategies, the situation would be less confrontational and better for the urban tree population, better for sustainability and better for the built structures. The challenge has been laid down, and it is for local authorities to work with the technical professionals and take up the gauntlet.

\section{Acknowledgments}

The assistance of Michael Lawson and Les Round, Managing Director and Scientific Officer respectively at OCA, in the preparation of this paper is gratefully acknowledged. The authors also acknowledge the critical 
input of Giles Mercer of OCA and the help and support of Christine Oakes and the OCA administration team.

\section{References}

Batho, J. (1990) Final Report on a Review of the Tree Preservation Order System, Department of the Environment, London, UK (out of print).

Biddle, PG. (1998) Tree Root Damage to Buildings: Volume 1, Causes, Diagnosis and Remedy, Willowmead Publishing Ltd, Oxford, UK (Chapter 10, pp. 157-170).

British Standards Institute (BSI) (1990) Methods of test for soils for civil engineering purposes: Classification tests, BS1377: Part 2, paragraphs 4.1 to 4.3.5, BSI Publications, London, UK.

Building Research Establishment (BRE) (2001) Geotechnical Report No. 128/12, Queens Park Estate, London W10, BRE, Garston, Watford, UK.

Davey Resource Group (1993) Consolidating and Communicating Urban Forest Benefits, ISA Publications, Champaign, IL, USA.

DETR (1991) Trees in Focus, HMSO, London, UK.

Hipps, N. (2004) 'Controlling Water Use of Trees to Alleviate Subsidence Risk', Horticulture LINK Project 212, Final Report Executive Summary, East Malling Research and University of Cambridge, UK.

Lawson, M. (1993) 'Trees, clay \& climate', in Housing Subsidence, Proceedings of the Geological Society Conference, London, UK.

Lawson, M. (2004) 'Tree related subsidence of low-rise buildings and the management options', Arboric Journal, 27(3), 191-219.

Lawson, M and O'Callaghan, DP. (1995) 'A critical analysis of the role of trees in damage to low rise buildings', Journal of Arboriculture (USA), 21(2), 90-97.

Marsh, TJ and Monkhouse, RA. (1992), Drought in the United Kingdom, 1988-1992, 15-22, London, UK.

Meteorological Office (2004) Meteorological Office Rainfall and Evapotranspirational Calculating System (MORECS), 'Square 106 data set', HMSO and Meteorological Office, Legal Consulting, Fast Net 1, Exeter, UK.

National House Building Council (NHBC) (2003) Chapter 4.2: Building Near Trees, NHBC Publications).

National Urban Forestry Unit (NUFU) (1998) Trees Matter - The Benefits of Trees and Woodlands in Towns, NUFU Publications, Wolverhampton, UK.

National Urban Forestry Unit (NUFU) (2005) Trees Matter - Bringing Benefits of Trees to People in Towns, NUFU Publications, Wolverhampton, UK.

O'Callaghan, DP and Lawson, M. (1995) 'A critical look at the potential for foundation damage caused by tree roots', in Watson, G, Neely, D Eds., Proceedings of Trees and Buildings Conference, May 1995, Lisle, IL, USA.

Ward, WH. (1947) 'The effects of fast growing trees and shrubs on shallow foundations', Journal of the Institute of Architects, 11, RIBA Publications.

\section{FURTHER READING}

Lawson, M. (1996) 'Vegetation and sustainable cities', Arboric Journal, 20 